\title{
Characteristics and Principles to Apply Project-based Teaching Method in Life Ceramics Course
}

Fei Yua

The Department of Art and Design, Jingdezhen University, Jingdezhen, Jiangxi, China

\begin{abstract}
The application of project-based teaching method in life ceramics course is mainly divided into three major types: studio type, practice base type and people-oriented type, with distinctive features of clear objectives, remarkable innovation, strong practicality and diverse interaction. Principles of integrity, autonomy, moderation, cooperation, creativity and comprehensiveness are supposed to be adopted in the application.
\end{abstract}

\section{Introduction}

As an excellent teaching mode to cultivate students' practice ability and creative thinking ability, projectbased teaching method has been held in esteem internationally for a long time. Not much attention has been paid to it in China on account of the influence of long-term traditional education methods. It starts late without being fully developed in many course fields till today, among which include life ceramics course. It will change traditional teaching methods to launch projectbased teaching in life ceramics course, which is in line with the requirements of the times and social needs more; thus, project-based teaching method shall become an important development direction of life ceramics course reform. Teachers of life ceramics course are supposed to be active in analyzing the application rule of projectbased teaching method in life ceramics course, and grasping its application features and principles, in order to develop project-based teaching better.

\section{The application type of project-based teaching method in life ceramics course}

Project-based teaching method is a rather pop modern teaching way, which differs from traditional classroom teaching method. It leads teaching by means of projects, stimulates students' interest, integrates their professional knowledge, and strengthen skill training. Life ceramics is a course to design and make life pottery works, which emphasizes practicality, hence it is very suitable for the application of project-based teaching method. The application of the method in life ceramics course could roughly be divided into three types, that is, project-based teaching method of studio type, practice base type and people-oriented type.

The project-based teaching method of studio type of life ceramics course refers to the project-based teaching method that is carried out on the basis of the pottery studio on campus. The project-based teaching method of studio type of life ceramics course can be divided into two kinds: one is that teachers of life ceramics course launch teaching events in strict accordance with the teaching plan, divide the teaching content and set it as small projects to be finished by students themselves; it is a relatively closed teaching method, projects are virtual projects set by teachers, similar with homework; another is that teachers of life ceramics course bring the practical part of their own research projects that are related to life ceramics into the studio, develop teaching in the way that teachers and students jointly complete scientific research projects; it is a more flexible teaching method.

The project-based teaching method of practice base type of life ceramics course refers to the project-based teaching method that is carried out on the basis of the practice base off campus. Most qualified colleges that open the ceramics major own practice bases off campus. Some colleges located in non-porcelain producing areas set up practice bases in porcelain-producing areas one after another in addition to that colleges located in porcelain-producing areas are richly endowed by nature with unique advantages, which creates more favorable conditions for the project-based teaching of life ceramics course. Being compared with the project-based teaching method of studio type, the project-based teaching method of practice base type appears to be more open, teachers and students complete the life ceramics project together at the practice base that is built in ceramic industrial park or ceramic enterprises, and achieve the teaching objective.

The project-based teaching method of people-oriented type of life ceramics course refers to the project-based teaching method that takes students' innovation and entrepreneurship as the leading direction. It is a more open and flexible project-based teaching method of life ceramics course. Being student-oriented, it is to go to

\footnotetext{
a Feiyu:653104053@qq.com
} 
ceramic industrial park or enterprises to look for, choose, and complete projects independently, give full play to students' autonomy, initiative and creativity, and teachers play their guiding role. With human development as its essential purpose, the project-based teaching method of people-oriented type of life ceramics course makes the best use of human intelligence and skills, and helps students to obtain better entrepreneurship and employment opportunities and prospects.

\section{The application features of the project- based teaching method in life ceramics course}

\subsection{Clear objectives}

It is dull and boring to teach life ceramics course with traditional teaching methods, often echoing what books say without truly clear teaching objectives. And students are lack of initiative and enthusiasm of learning. While with project-based teaching method, the life ceramics course takes it as its very clear and practical teaching purpose to finish the project, different from the established teaching objective in textbooks. Inspired by this clear goal, students have stronger motive to learn, their creativity is fully aroused, and their practice ability and ability to solve practical problems have been greatly improved.

\subsection{Remarkable innovation}

Being compared with traditional teaching methods, the project-based teaching method of life ceramics course possesses remarkable innovation in all teaching links. Firstly, the teaching method that gives first place to teacher's lectures is innovated as the teaching method that gives priority to students' autonomic learning, and students become the main body of teaching. Secondly, textbook-centered teaching method is innovated as project-centred teaching method, changing project content takes the place of established textbook contents. Thirdly, classroom-centered teaching method is innovated as the teaching method based on studio and practice base, which makes teaching events exceed the classroom and school.

\subsection{Strong practicality}

Students' chances of practice and operation are in want in traditional classroom teaching method of life ceramics course, besides that practice content is not all-around, while the project-based teaching of life ceramics course makes it available for students to take part in the complete practice and operation in the project by themselves who are driven by actual projects, carry out all sorts of practice events to finish the project, practice is necessary in all links of design, molding, painting, and heating, practical creation skill is improved increasingly; meanwhile, relevant speculative knowledge is to be grasped and combined with practical operation.

\subsection{Diverse interaction}

The project-based teaching of life ceramics course is aimed at multi-party cooperation to accomplish the project together with a very distinctive feature of interaction. Firstly, the interaction between teachers and students. The interaction and communication between teachers and students have to go on constantly in order to finish the project, teachers guide students, and solve the problems and questions that are put forward by students, and give students advice and opinions on finishing the project; secondly, the interaction among students. Division of labour and collaboration among students are necessary to finish the project, and they discuss methods to solve problems together; thirdly, the interaction between teachers and students and the society. If the project is off campus, teachers and students have to communicate with social forces that are related to the project, including ceramic park, ceramic enterprises and individuals. Only through multi-party interaction can the project objective be achieved.

\section{The application principle of project- based teaching in life ceramics course}

\subsection{Principle of integrity}

The application of the project-based teaching method in life ceramics course should be complete and full projectbased teaching event. A teaching entirety consists of from project determination, project plan, project implementation to project evaluation, only in this way, a truly effective project-based teaching process is composed so that students could get overall training and improvement from skills to knowledge.

\subsection{Principle of autonomy}

The application of the project-based teaching method in life ceramics course not only lays stress on the result of project practice, but also emphasizes the process of project completion more. Student-centred, the project is finished while cultivating and exercising students' capacity of will, so that students are enabled to independently finish the whole process from raw material preparation, work design, production to burning in the life ceramics project, and solve all sorts of problems in the project completion process.

\subsection{Principle of moderation}

The application of the project-based teaching method in life ceramics course is supposed to be moderate in difficulty. The chosen project shall guarantee that most students can achieve the goal to complete the project through their own efforts according to students' existing actual level and knowledge quality, so that most students' enthusiasm could be stirred up, instead of frustrating them on account of the difficulty of the project, nor that students' practice ability can not be really improved 
because of the easiness of the project.

\subsection{Principle of cooperation}

The application of the project-based teaching method in life ceramics course lays stress on the collective strength of teachers and students, so that the project objective is achieved by means of the unity and cooperation between teachers and students. In the course of completing the goal, each student must be subordinate to the collective, and each student's individual ability should be ensured to be fully demonstrated and exerted, and students' team spirit and collective consciousness be fully cultivated at the same time.

\subsection{Principle of creativity}

The application of the project-based teaching method in life ceramics course is a creative teaching method, whose creativity refers not only to the teaching method itself, more importantly to that students shall take the initiative to exert their creativity and imagination in the process of completing the life ceramics project, and teachers shall inspire and guide them to exert their creativity fully, so as to cultivate students' artistic creativity ability to the full.

\subsection{Principle of comprehensiveness}

The application of the project-based teaching method in life ceramics course is comprehensive, students must make full use of their practice skill and theoretical knowledge that they have learned to solve all problems in the process of completion of the project, and teachers should adopt comprehensive principle to assess students, focus on observing and paying close attention to the overall comprehensive performance in the process to complete the project, doing their best to evaluate comprehensively, impartially and objectively.

\section{References}

1. Chen Jun. On Education of Life Ceramic Design [J]. Sea of Art, 2008 (02).

2. Li Huiying. Design and Application Research of Project-based Teaching [D]. Shenyang Normal University, 2014.

3. Huang Sheng. On the Reform of the Combiantion of Teaching of Life Ceramics Course with Market [J]. Art Education, 2006 (11).

4. Wang qingli \& Zhang Ganglin: Ceramic Education and Open Learning [J]. New Fine Art, 2013 (12). 